\title{
Environmental Studies Data Base Development and Data Synthesis Activities of the U.S. Subseabed Disposal Program
}

Leo S. Gomez, Melvin G. Marietta, R. R. Hessler

K. L. Smith, Jr., A. A. Yayanos, D. W. Jackson

Prepared by Sandia National Laboratories, Albuquerque, New Mexico 87185 


\section{DISCLAIMER}

This report was prepared as an account of work sponsored by an agency of the United States Government. Neither the United States Government nor any agency Thereof, nor any of their employees, makes any warranty, express or implied, or assumes any legal liability or responsibility for the accuracy, completeness, or usefulness of any information, apparatus, product, or process disclosed, or represents that its use would not infringe privately owned rights. Reference herein to any specific commercial product, process, or service by trade name, trademark, manufacturer, or otherwise does not necessarily constitute or imply its endorsement, recommendation, or favoring by the United States Government or any agency thereof. The views and opinions of authors expressed herein do not necessarily state or reflect those of the United States Government or any agency thereof. 


\section{DISCLAIMER}

Portions of this document may be illegible in electronic image products. Images are produced from the best available original document. 
Issued by Sandia National Laboratories, operated tor the United Slales Department of Energy by Sandia Corporation.

NOTICF: This report was prepared as an account of work sponsored by an agency of the United States Government. Neither the United States Government nor any agency therenf nor any of their employees, nor any of their contractors, subcontractors, or their employees makes any warranty, express or implied, or assumes any legal liability or responsibility for the accuracy, completeness, or usefulness of any information, apparatus. product, or process disclosed, or represents that its use would not infringe privately owned rights. Reference herein to any specific commercial product, process, or service by trade name, trademark, manufacturer, or otherwise, does not necessarily constitute or mply its endorsement, recommendation, or favoring by the United States Government, any agency thereof or any of their contractors or subcontractors. The views and opinions expressed herein do not necessarily state or reflect those of the United States Government, any agency thereof or any of their contractors or subcontractors.

Printed in the United States of America Available from

National Technical Information Service

U.S. Department of Commerce

5285 Port Royal Road

Springfield, VA 22161

NTIS price codes

Printed copy: $\$ 5.00$

Mirrofiche copy: A01 


\section{PAGES 1 to 2 WERE INTENTIONALLY LEFT BLANK}




\title{
Environmental Studies Data Base Development and Data Synthesis Activities of the U.S. Subseabed Disposal Program
}

\author{
Leo S. Gomez \\ Seabed Programs Division 4536 \\ Melvin G. Marietta \\ Applied Mechanical Division 5521 \\ Sandia National Laboratories \\ Albuquerque, NM 87185 \\ R. R. Hessler \\ K. L. Smith, Jr. \\ A. A. Yayanos \\ University of California \\ Scripps Institution of Oceanography \\ La Jolla, CA 92093 \\ D. W. Jackson \\ Concepts Development, Incorporated \\ Alhuquerque, NM 87106
}

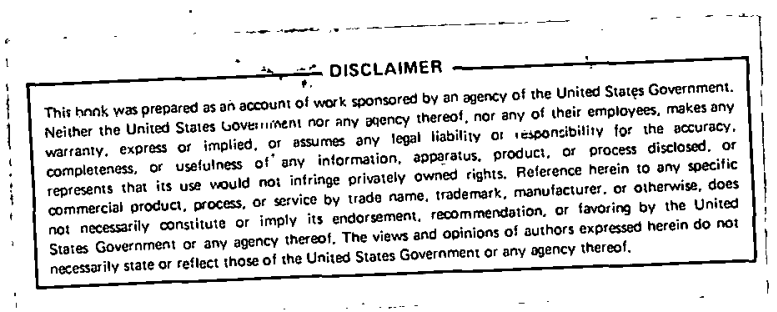

\begin{abstract}
The U.S. Subseabed Disposal Program is assessing the scientific feasibility of subseabed emplacement of high-level nuelcar wastes. Studies of disposal methods and of the barriers to radionuclide migration (canister, waste form, and sediment) suggest that environmental information will be iteeded to address the impact of accidental release of radionuclides in the deep sea.

Biological, physical, and geochemical data are being collected from field and laboratory studies as well as from literature searches. These data are being analyzed using a multicompartmental radionuclide transport model and appropriate physical oceanographic models. The data integrated into this framework will help answer two questions--what are the environmental effects of radionuclides that may be released in the deep sea, and what are the effects of such a release upon man?
\end{abstract}




\section{Contents}

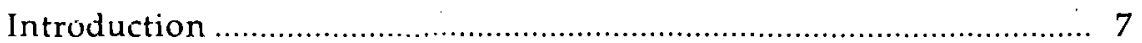

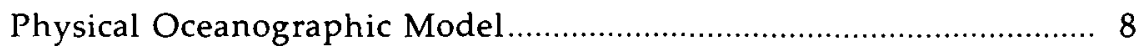

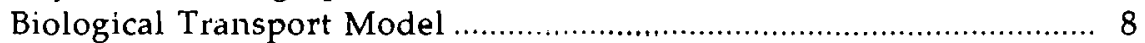

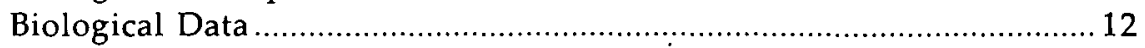

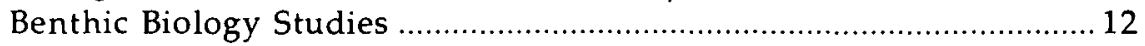

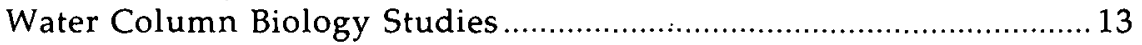

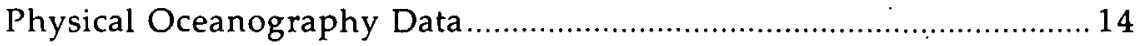

Recommendations of the SDP Physical Oceanographic Workshop....14

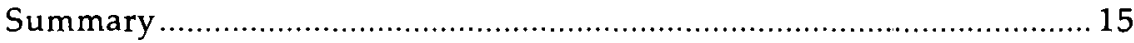

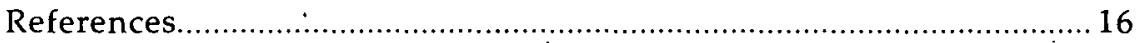

\section{Illustrations}

Figure

1 Ion Transport Analysis Model

2 Thermal Inactivation of the Bacterial Strain CNPT-3 Isolated From a 5,700-m Depth in the Central North

Pacific Ocean.

3 Pressure Dependence vs Generation Time of Bacterial Strain CNPT-3 Isolated From 5,700-m Depth in the Central North Pacific Ocean

\section{Tables}

Table

1 Calculation of Mass Densities

2 Calculation of Uptake Times 


\section{Environmental Studies Data Base Development and Data Synthesis Activities of the U.S. Subseabed Disposal Program}

\section{Introduction}

In assessing the scientific feasibility of subseabed emplacement of high-level nuclear wastes (HLW), the U.S. Subseabed Disposal Program (SDP) is collecting and evaluating information about radionulcide transport in the relatively unknown environment of the deep sea. As part of this program, the SDP Biology Team is charged with gathering information regarding the kinds, amounts, distribution patterns, and activity rates of deep-sea fauna.

Data obtained from field and laboratory studies and literature searches are analyzed using a multicompartmental radionuclide transport model. 12 This model provides a theoretical framework for evaluating (through parametric study) the assumptions made regarding the transport of radionuclides from a given waste form.

The questions that need to be answered concerning environmental and human dose effects require that the radionuclide transport from the canister to man which might result from an accidental emplacement failure be quantitatively defined. For the general situation, one can assume that the canister has been emplaced within the sediments, perhaps at a shallow depth, and leakage occurs. Then the probability of occurrence must be determined for various concentrations of radionuclides, as a function of space and time, in materials which lead to doses to both the marine biota for environmerital effects and to humans for human effects.

This is a complex problem with many interáctions and feedbacks, but the essential calculation that must move forward in time and space scales can be divided into parts in a natural, but not unique, way (Figure 1). A model of the waste form and canister package is required to provide a definition of the source function for the ion transport problem.

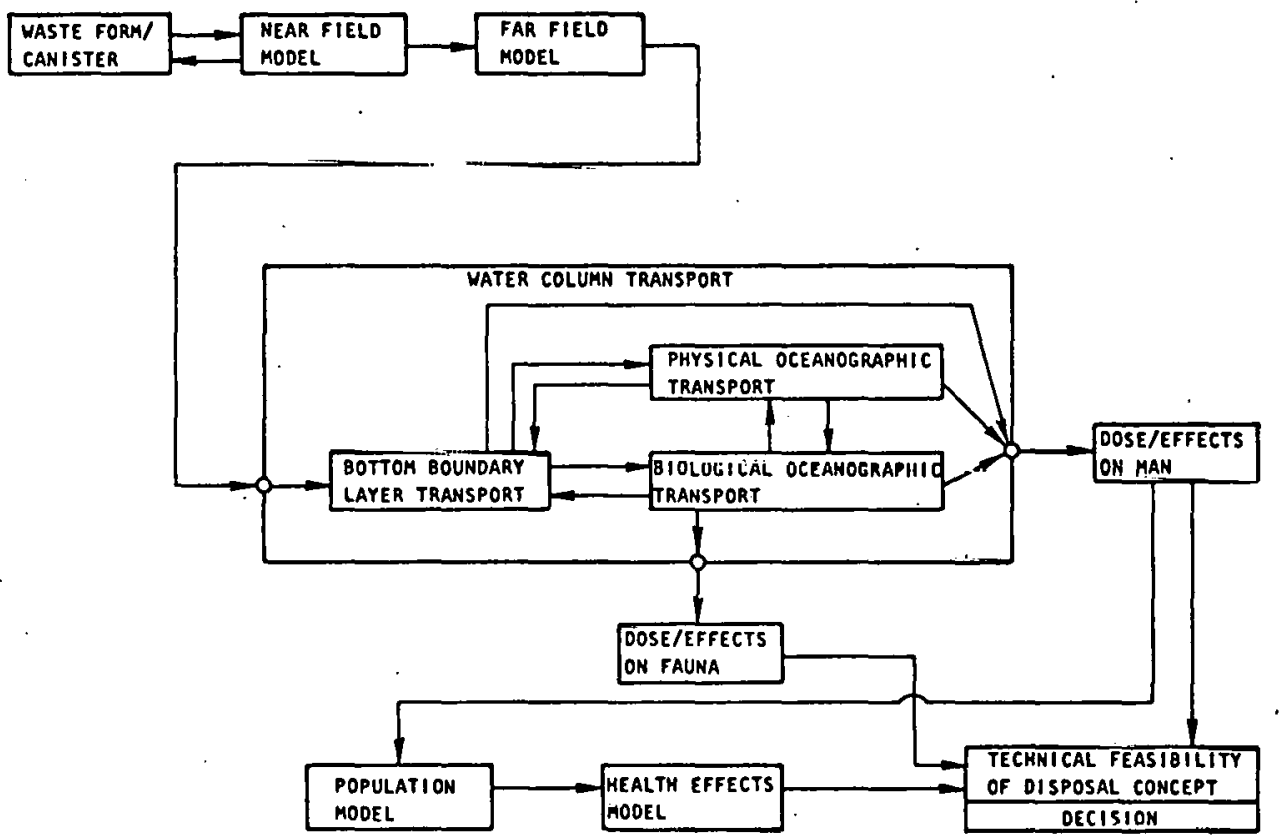

Figure 1. Ion Transport Analysis Model 
The region around the canister where thermal effects are important is called the near field. If the thermal loading is low enough that thermal effects near the canister are not important, there is no nearfield ion transport problem, and only the isothermal far-field case must be considered. For the iterative process that leads to the source defintion, it is essential to model the near field.

The far-field calculation provides the radionuclide fluxes and pore water velocity fields in the sediments. This calculation must account for bioturbation effects in the upper few centimeters of the sediments and then provide the concentration field at the sediment surface.

The radioisotope migration must be quantitatively traced from the sediment-water interface into materials which lead to doses to man or exposures of the biota. Fisheries models for affected marine foods, including the human populations feeding upon these foods, will be required for population dose effects sludies. Hazard assessments for a single individual or a special segment of the affected human population are hypothetical calculations for a particular scenario.

l' $h$ he part of the ion-transport problem discussed here is the water column. This involves the interactions of physical, geochemical, and biological processesses in the open ocean as they relate to radioisotope transport.

\section{Physical Oceanographic Model}

The transport problem through the water column is to trace the dispersal of a pollutant plume from a bottom source with small initial dimensions through increasing space and time scales to the surface, while accounting for important biological and geochemical processes. The approach to this problem draws upon existing modeling expertise as follows:

First, a bottom boundary layer model is required. This should include a sediment transport model and the biological processes that are important in the lowest $100 \mathrm{~m}$. Currently, a second-order turbulence closure model ${ }^{3}{ }^{4}$ is being modified for the special purposes of this disposal problem.

Second, a regional eddy-resolving model is required. This should include suspended-particulate transport with the important geochemical and biological processes that can be resolved in this tens-ofkilometers grid spacing, with smaller scale processes represented through subgrid parameterizations. Currently, the Harvard finite-element barotropic open ocean model ${ }^{56}$ is being modified to meet this requirement.
Third, a larger scale model with a grid scale of hundreds of kilometers ${ }^{7}$ is required. Again, many modifications of the model for this disposal problem are necessary, and this work is just beginning.

Additional modeling research questions must be answered in the near future to study the dispersal of a pollutant plume from a bottom source. Some of the high priority questions are:

- How does one interface models of different space scales containing different physical processes in a realistic way?

- How can one handle topographic and coastal effects properly in these models?

- How does one realistically interface biological transport with physical dispersion?

- How can one handle the important processes such as bottom boundary layer detachment or soliton-like transport within these models?

A more complete discussion is contained in the SDP Physical Oceanography Workshop report. ${ }^{8}$

\section{Biological Transport Model}

Existing models of radionuclide dispersal in the marine environment have largely ignored biological transport and assumed physical dispersion processes to be the overriding consideration. In these models marine biota simply accumulate radionuclides from water according to concentration factors, and lose their body burden according to biological half-lives. To thoroughly assess possible hazards associated with subseabed disposal of radioactive waste, a multicompartment model is under development that considers both physical and biological transport. Physical oceanographic aspects of this effort were discussed in the preceding section; in this section biological considerations included in the model are set forth.

The initial goal of the biological transport modeling effort is to formulate a mathematical model capable of simulating the SDP Biolugy Team's understanding of the flow of potential radionuclidecarrying material through the biotic system, assuming a biological steady state and a closed system. The next step is to interface the important processes in a realistic fashion with the physical oceanographic models. The initial compartmental model was constructed to allow the coupling of the biological and physical processes of similar space and time scales. This initial model is not an ecosystem model; it is a framework for assessing, through careful parametric study, the results of assumptions regarding release 
and transport of certain radionuclides from a given waste form. No attempt is made, at this stage, to account for interactions between population dynamics, physicochemical variables, nutrients kinetics, etc, that are often considerations in an ecosystem model.

In keeping with the findings of researchers in the area of heavy metal and radionuclide kinctics in aquatic animals, it is assumed that the two major pathways for radionuclide uptake are uptake via food and uptake directly from water. ${ }^{10}$ It is useful to divide "food" into biomass and particle mass. Thus, the SDP Biotransport Model is designed to simulate the flow of three radionuclide-carrying material categories: water mass, particle mass (sediment and suspended particulates), and biomass. These material categories are considered in submodels: a euphotic zone submodel, midwater zone submodels, and a sediment/benthic boundary zone submodel.

In the context of this work, compartmentalization refers to the division of the ecosystem into recognizable components which contain, at any time, a certain amount of radionuclide-carrying material. In the compartmental model, each compartment is a state variable, defined as sets of numbers used to represent the state, or condition (in the case, the radionuclide concentration) of the system at any time. ${ }^{11}$ These compartments are connected by the movement of radionuclide-bearing material, forming an interactive web.

The next step in the compartmentalization procedure is to divide the web of compartments along natural boundaries imposed by the system. In the deep $(\sim 5000-\mathrm{m})$ marine ecosystem under consideration, two natural zones appear to be the water column and the sediment/benthic boundary zone. The water column is further divided into a euphotic zone $(0$ to $200 \mathrm{~m})$, in which most oceanic binlngical activity occurs, and a midwater zone. Since biological states and rates vary significantly with depth, the midwater zone is further subdivided into horizontal layers, analogous to the layered physical oceanographic models.

Since the biomass material compartments represent organisms in the submudels, these compartments are divided into functional groups of organisms (e.g., phytoplankturt, pelagic animals, sediment. infauna) to allow simulation of differential uptake and transport of radionuclides by organisms in functional groups. ${ }^{2}$ The basis for this division is largely the result of spatial considerations (which are ultimately sampling considerations), although effort is made to include trophic considerations as well.

Details of compartmentalization were presented and discussed in a previous paper, ${ }^{2}$ but it is important to point out the hierarchical nature of this scheme. This hierarchical formulation allows the inclusion of increasing levels of detail through mudification of existing compartments. For example, starting with a sediment compartment, one can move to infaural, interstitial water, and solid matrix compartments, all within the sediment compartment. Further refinement could be made within the solid matrix compartment by adding bacterial and particulate compartments, etc. Since the entire biological transport model has been formulated in this hierarchical manner, parametric studies may be initiated on a very simple model and moved to increasing levels of detail according to the sensitivities identified.

With the model's conceptual framework established, this system of compartments and arrows is translated into a system of ordinary differential equations describing the time-dependent change in radionuclide concentration for each compartment. The fluxes defined in the conceptual framework (equations) define, in a general way, the parameters to be considered in the model and indicate the kind of observable data required to exercise the model. It has been useful to devise algorithms for most biological parameters to clearly identify various data and their sources used in a calculation. Tables 1 and 2 present the data and algorithms used to calculate values for biological parameters.

Referring to Tables 1 and 2, two definitions are in order. First, "mass density" is defined in the model as kilograms wet weight mass of compartment material per square or cubic meter, respectively, of sedimentwater interface or water. Second, "uptake time". is defined as the time, in years, required for a biological compartment to take up the fraction $u_{1}(\alpha=0.50$, arbitrarily chosen) of its mass from another compartment. Through exercise of the biological transport model, understandings are reached regarding the interaction between parameters and their relative sensitivities. These understandings lead to the ability to interface biological and physical transport models, as well as the various other models described in the Introduction. The resulting system of models provides a framework for predicting radiuniuclide doses to the human population, as well as environmental effects associated with subseabed disposal of radioactive wastes. 
Table 1. Calculation of Mass Densities

Model Parameter

FPI (Epibenthic Fauna)
Algorithm

None used

\section{Data}

$0.79 \pm 0.86 \mathrm{~g}^{*} \mathrm{~m}^{-2}$ $\sim 1 \mathrm{~g}^{*} \mathrm{~m}^{-2}$
Notes

Ten values from below $4000 \mathrm{~m}$ reported from the N. Atlantic and N. Pacific.

\begin{tabular}{|c|c|c|c|c|}
\hline INF (Infauna) & None used & $\begin{array}{l}0.70 \pm 0.74 \mathrm{~g}^{*} \mathrm{~m}^{-2} \\
\sim 1 \mathrm{~g}^{*} \mathrm{~m}^{-2}\end{array}$ & $17,14,18$ & $\begin{array}{l}\text { Five values from below } \\
4000 \mathrm{~m} \text { from the } \mathrm{N} \text {. Pa- } \\
\text { cific and Mediterra- } \\
\text { nean. }\end{array}$ \\
\hline
\end{tabular}

\begin{tabular}{llrr}
\hline PEL $_{\mathrm{n}}$ (Pelagic Fauna) & $\rho=4150 \mathrm{z}^{-1.12}=$ mass density & $\mathrm{z}$ & $\rho$ \\
& in $\mathrm{mg}^{*} \mathrm{~m}^{-3}$ wet weight at a giv- & 100 & 24 \\
& en depth, $\mathrm{z}$, in meters & 1000 & 2 \\
& & 3000 & 0.5 \\
& & 4000 & 0.4
\end{tabular}

19 Net mesoplankton data from the Sargasso Sea representinty elghi ubEervations down to 3500 iil. The data were fitted to a power law.

$\overline{D E T}_{n}$ (Detritus)

$\rho=\left(105.4 \mathrm{z}^{-0.52}\right)(0.058)^{-1}=$
mass density in $\mathrm{mg}^{*} \mathrm{~m}^{-3}$ wet weight at a given depth, $z$, in meters; 0.058 is a conversion factor to convert carbon mass to $\mathbf{4 0 0 0}$ wet-weight mass.

$\begin{array}{rrr}z & \rho & 20.2 \\ 100 & 166 & \\ 1000 & 50 & \\ 3000 & 28 & \\ 4000 & 24\end{array}$

Partirulate sarbon data from the $\mathrm{N}$. Atlantic and central Pacific representing five observations down to 3000 $\mathrm{m}$. The data were fitted to a powcr law and converted to units of wetweight mass.

$\rho=\frac{(\mathrm{ch}-\mathrm{a})\left(\mathrm{K}_{1}\right)}{\mathrm{K}_{2}}=$
mass density in $\mathrm{mg}^{*} \mathrm{~m}=\mathrm{a}$ wct weight.

ch-a = chlorophyll-a concentration in ing * ${ }_{111} 0.057$

$K_{-1}-a$ factor to convert ch-a to phytoplankton carbon, 60 $\mathrm{K}_{2}=\mathrm{a}$ factor to convert phytoplankton carbon mass to wetweight mass ch-a is mean based on 216 observations from 0 to $200 \mathrm{~m}$ in the N. Pacific gyre area.
22,23

24

25 
Table 2. Calculation of Uptake Times

Model Parameter WAT (Water)
Algorithm

$\tau=(W I R)^{-1 *} a$

WIR $=$ water intake rate $\cdot$ as mass of water taken up per unit mass of organism $10 \mathrm{~kg}$

WAT $/ \mathrm{kg}$ organism day ${ }^{-1}$

$\alpha=0.5$
$\tau=\left[\frac{\left(\mathrm{OCR}_{1}\right)\left(\mathrm{K}^{3}\right)\left(\mathrm{df}_{1, j}\right)}{\mathrm{K}_{\mathrm{i}}}\right]^{-1}(\alpha)\left(\rho_{1}\right)$

OCR $=$ oxygen consumption for EPI, $0.36 \mathrm{~mL} 0_{2} / \mathrm{m}^{2 *} \mathrm{~h}^{-1}$

$\mathrm{K}_{3}=$ factor to convert oxygen to carbon consumed, 0.38

$\mathrm{EPI} \leftarrow \mathrm{DET}$

$\mathrm{EPI} \leftarrow$ INF

EPI $\leftarrow$ MAT

(Solid Matrix)

EPI $\leftarrow$ INW

(Interstitial Water)

INF $\leftarrow$ DET

$\mathrm{INF} \leftarrow \mathrm{MAT}$

INF — INW

$\mathrm{df}_{1, j}=$ fraction of EPI's carbon consumption taken from $j^{\text {th }}$ compartment, arbitrary

$\mathrm{K}_{\mathrm{j}}=$ factor to convert carbon from $j^{\text {th }}$ compartment to wetweight mass, 0.068

$\alpha=0.5$

$\rho_{1}=$ mass density for EPI

Assume water content of sediment is $150 \%$ of dry weight

Same as for EPI

$15 \mathrm{~h}$

$102 \mathrm{~d}$

$\begin{array}{rcc}102 \mathrm{~d} & \text { Same } & \\ 8 \mathrm{~h} & \text { as } & \text { Same as EPI } \\ 5 \mathrm{~h} & \text { EPI } & \end{array}$

$5 \mathrm{~h}$

$\tau=\left[\frac{\mathrm{FR} * \mathrm{df}}{\mathrm{K}_{\mathrm{j}}}\right]^{-1} * \alpha$

$\mathrm{PEL}_{1} \leftarrow$ EPI

$\mathrm{PEL}_{1}-\mathrm{DET}_{1}$

$\mathrm{PEL}_{1} \leftarrow \mathrm{PEL}_{2}$

$\mathrm{PEL}_{2} \leftarrow \mathrm{PEL}_{1}$

$\mathrm{PEL}_{2} \leftarrow \mathrm{DET}_{2}$

$\mathrm{PEL}_{2} \leftarrow \mathrm{PEL}_{3}$

$\mathrm{FR}=$ feeding rate $\mathrm{mgC} / \mathrm{mg}$ organism $y^{-1}$ at a given depth $(z)$ as predicted from: $\log F R=$ $1.8595+\log z(-0.7445)$

$\mathrm{df}=$ fraction of the pelagic animal compartment's feeding rate obtained from another compartment

$\mathrm{K}_{\mathrm{j}}=$ conversion factor to convert carbon consumed to wetweight mass cursumed, 0.068

$$
\begin{aligned}
& \mathrm{PEL}_{3} \leftarrow \mathrm{PEL}_{2} \\
& \mathrm{PEL}_{3} \leftarrow \mathrm{DET}_{3} \\
& \mathrm{PEL}_{3} \leftarrow \mathrm{PEL}_{4} \\
& \mathrm{PEL}_{4} \leftarrow \mathrm{PEL}_{3} \\
& \mathrm{PEL}_{4} \leftarrow \mathrm{DET}_{4} \\
& \mathrm{PEL}_{4} \leftarrow \mathrm{PP}
\end{aligned}
$$

Data

$1.2 \mathrm{~h}$
References

26

\section{$69 \mathrm{~d}$}

$40 \mathrm{~d}$
27

28

\section{Notes}

This represents an upper bound on water uptake by all organism compartments. Data are from laboratory work with shallow water marine shrimp.
Oxygen consumption is one-half of mean of five observations from a mean depth of $4877 \pm$ $1081 \mathrm{~m}$. The other half is used for INF.

$10 \mathrm{~h}$

$310 \mathrm{~d}$

$310 \mathrm{~d}$

$155 \mathrm{~d}$

$146 \mathrm{~d}$

$146 \mathrm{~d}$

$73 \mathrm{~d}$

$21 \mathrm{~d}$

$21 \mathrm{~d}$

$10 \mathrm{~d}$ 


\section{Biological Data}

In ecological field and laboratory investigations, it is difficult to adequately address all important aspects of the ecosystem under study. In order to satisfy data requirements defined by an ecosystem model, it is necessary to review data reported in the literature from similar ecosystems. Since the SDP Biology Program has been operating for a relatively short time, data from the literature constitute a large portion of the current SDP biological data base. This review and analysis of historical data represents a continuing SDP activity directed primarily at providing input data for the SDP Biological Transport Model discussed above.

Historical data analysis in the area of biological uceanography has concentrated on work done in the deep oligotrophic regions of the Atlantic and Pacific. Data are oryanized under four main headings: water column densities, water column rates, benthic boundary zone densities, and benthic boundary zone rates. These zones were discussed in the section on the Biological Transport Model. Additionally, an extensive bibliography on radiation effects on aquatic biota has been compiled for the SDP. ${ }^{30}$

Water-column biomass densities include measurements of

(a) Phytoplankton chlorophyll-a concentrations

(b) Zooplankton densities measured as dry or wet weight, carbon or nitrogen weight, and displacement volumn

(c) Bacterial densities measured as cells per unit volume or ATP equivalents

(d) Detritus densities measured as particulate organic carbon.

There are few estimates of nekton densities, which are often simply estimated as a fraction of phytoplankton or zooplankton density. Of special interest is the way these densities change with depth; data from a few deep-water studies have been fitted to a regression curve to provide estimates of zooplankton density at great depths.

Water column rates include measurements of

(a) Phytoplankton carbon production rates and doubling time

(b) Bacterial carbon consumption rates

(c) Food ingestion rates for zooplankton and nekton based on measurements of oxygen consumption, prey consumption, percent of body weight consumed, and filtering rates

(d) Egestion rates of zooplankton based on fecal pellet production rates

(e) Sinking rates for zooplankton eggs, molts, fecal pellets, and dead animals
As with water column biomass densities, ingestion rates are fitted to a regression curve to provide extrapolations of these rates to required depths.

Benthic boundary zone biomass densities include measurements of

(a) Sediment bulk density, water content, and organic matter content

(b) Benthic animal densities for meiofauna, macrofauna, and megafauna measured as numbers and biomass

(c) Sediment bacteria densities measured as cells per unit area or ATP equivalent.

Benthic boundary zone rates include measurements of oxygen consumption by abyssal benthir communities, sediment bacteria generation times, and sedimentation rates as determined from sediment-core samples. In the benthic boundary zone a significant portion of the data have been generated by SDP activities, especially oxygen-consumption rates and animal densities. ${ }^{27}$ Finally, a collection of equivalents and correspondencies has been assembled from the literature to facilitate the expression of data in common units.

An effort is made to document, when possible, the variance in data obtained from the literature, along with any information that may assist in evaluating the reliability of the data. A discussion of how these data are used in calculating model-parameter values was presented in the section on the Biological Transport Model.

\section{Benthic Biology Studies}

The SDP benthic biology studies are focusing on the potential of benthic fauna to disperse or to concentrate any radionuclides that may leak from radioactive waste ranisters emplaced in dccp-ocean sediments. Included are studies of the nanobenthos, microbiota, meiofauna, macrofauna, and abyssopelagic scavengers. ${ }^{17} 31-33$

- Studies are continuing on the distribution and density of the microbiota, meiofaurla, and macroinfauna. These studies are important to the SDP, because these dre among the most abundant infauna and are at the base of a food web that may ultimately include man.

Amphipods, which are a large, highly mobile component of the deep-ocean benthic community, may potentially be very important in the mobilization of radionuclides released in the deep sea. The SDP has therefore focused much of its work on amphipods as representative of the mobile scavengers present in the deep sea. 
Historically, the inaccessibility of the deep ocean environment has permitted only a limited view of the functional aspects of this ecosystem. During the last decade, in situ and laboratory studies have suggested that biological rates in a deep-sea ecosystem may be much less than those in shallow water. ${ }^{34-40} \mathrm{~A}$ free vehicle grab respirometer (FVGR), developed to measure in situ activity rates of the benthic community including oxygen uptake and nutrient exchange, ${ }^{38}$ has been modified extensively so that the sediments on which these measurements are made can be returned to the ocean surface for biomass and other analyses. ${ }^{41}$ The FVGR can also be used to conduct in situ studies on the effects and fate of injected stable or low-level radiolabelled compounds.

Because of the need to understand deep-sea microbial processes, techniques are being developed for the cultivation and identification of deep-sea microbes. ${ }^{42} 43$ Several deep-sea microbes have been successfully isolated. A bacterium isolated from a depth of $5800 \mathrm{~m}$ in the Central North Pacific reproduces optimally in laboratory cultures at deep-sea pressures. ${ }^{44}$ Figure 2 shows typical data on the thermal inactivation of the deep-sea bacterial strain CNPT-3. The colony-forming ability of this bacterium decreases with increasing temperature. Evidence to date from this bacterium, as well as from other isolates, suggests that the deep-sea microbial population will stop functioning above $15^{\circ} \mathrm{C}$ at 580 bars, indicating that in the $100^{\circ} \mathrm{C}$ regions around high-level nuclear waste canisters, only spores of thermopilic bacteria could be viable. The barophilic nature of CNPT- 3 has also been demonstrated. ${ }^{45}$ Figure 3 shows the pressure dependence of the generation time of CNPT-3.

\section{Water Column Biology Studies}

Food energy exchange through the water column can be viewed as either active (flux of nutrients mediated by organism transport) or passive (sinking of particulate organic matter controlled primarily by gravitational forces). 4647

The upper layers of the ocean have in the past received the most study because of their accessibility. Recently, a free vehicle midwater gill net and baited trap-hook array (FVMNT) has been extensively used to characterize the abyssopelagic fauna. ${ }^{18}$ Benthopelagic organisms, such as fish and amphipods, have been captured hundreds of meters above the abyssal sea floor. ${ }^{48}$

A giant conical net $(100-\mathrm{m}$ diameter and $200 \mathrm{~m}$ long) will be used to help characterize the abyssopelagic faunta by capturing pelagic animals that elude capture by either smaller towed nets or the FVMNT array.

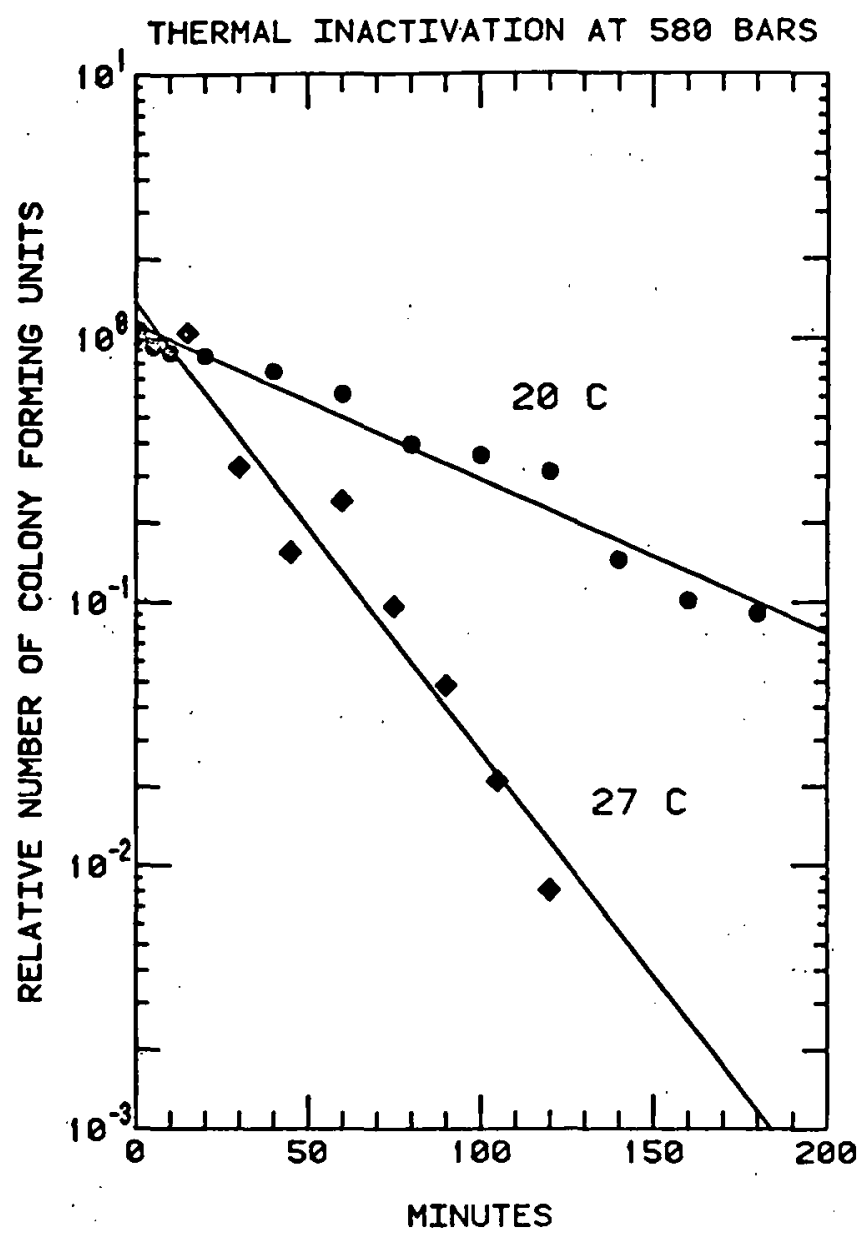

Figure 2. Thermal Inactivation of the Bacterial Strain CNPT-3 Isolated From a 5,700-m Depth in the Central North Pacific Ocean.

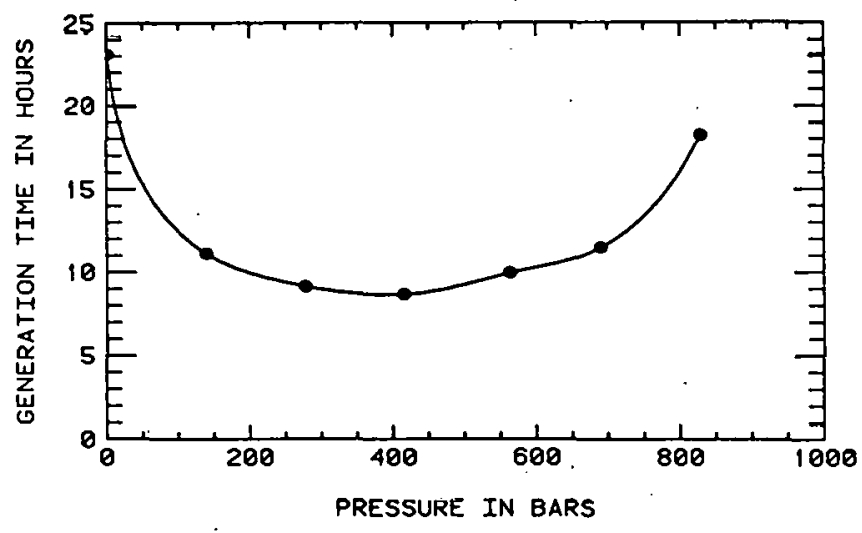

Figure 3. Pressure Dependence vs Generation Time of Bacterial Strain CNPT-3 Isolated From 5,700-m Depth in the Central North Pacific Ocean. 
A free vehicle for acoustically assessing abyssopelagic-animal population sizes and mobility rates is being developed at Scripps Institution of Oceanography for the SDP. This acoustical array will monitor for months the movements of abyssopelagic populations within a water column $1.9 \mathrm{~km}$ in diameter by $100 \mathrm{~m}$ high immediately above the abyssal sediment surface.

\section{Physical Oceanography Data}

Among the benefits of the MODE/POLYMODE program in recent years have been quite a few longtime records of current velocity which have been obtained in the deep North Atlantic, and some statistical characteristics of the variability of low frequency velocity fields. ${ }^{99}$ However, in the North Pacific, long-time records have not been available and the characteristics of the low-frequency velocity field are unknown. In 1974, the SDP began a current measurement program to obtain current records for a period of a year and a half in the deep North Pacific. Before the SDP study, Earles' $43-d$ records of currents ${ }^{50}$ were the only reported measurements made over a period longer than a week.

Near-bottom current measurements were made in the low abyssal hill region about $1000 \mathrm{~km}$ north of Hawaii. The objective of these measurements was to describe the low-frequency variability of the deep current field. These measurements represent the first set of long-term current meter records obtained for the deep subtropical North Pacific. A complete statistical characterization has been reported. ${ }^{51}$ For the puipuse of the SDP, this first study corroborated early laburatury studies, column could not serve as a barrier to radionuclide migration. Thus, early in the program the SDP turned to the sediments as a primary barrier, but has continued to study the water column in terms of the transfurt frubleme it precents.

Even though the water column is a barrier to man's intrusion, it will not impede pollutant migration on a time scale which is comparable to the halflives of the long-lived members of the waste inventory; it is necessary to assess the characteristic space and time scales of a pollutant release from a bottom source with small initial dimension. Kupferman has provided an overview of how the dispersal of a pollutant would proceed through increasing space scales from the sea bottom to the sea surface. ${ }^{53}$ In this program, for hazard assessment, it will be necessary to predict the streakiness that results from the stirring of a red patch of dye into red streaks (high concentration of a passive tracer) separated by clear streaks (low concentration of a passive tracer) as well as the "pinkness" that results from the molecular scale mixing of a red patch.

Since 1954, stratospheric debris from nuclear weapons tests has delivered measurable amounts of artificial radionuclides to the world ocean. Initially, oceanographic studies of this fallout concentrated on the long-lived radionuclides in the hope that they would trace water and particle movements over a long time scale. It is now known that Cs-137 and Sr90 trace water movements $(<5 \%$ association with particles), while the lanthanides, $\mathrm{Pu}, \mathrm{Am}$, and Fe-55, are largely particle-seekers. The temporal variations of the suluble fallout nuclides are relevant to plume dispersal, while the particle-seeker distributions provide information on the host particle sinking rates. ${ }^{54}$

Bowen et al55 have recently presented a new look at some GEOSECS $\mathrm{Pu}$ data which indicate that $\mathrm{Pu}$ may be used as a bottom water traccr in the North Pacific just as tritium is used as a bottom water tracer in the North Atlantic. The SDP has funded some of these $\mathrm{Fu}$ ineasurements in the past, and will continue to support this activity in order to exploit the potential of this tracer in understanding the deep Pacific circulation.

\section{Recommendations of the SDP Physical Oceanographic Workshop}

The SDP held a physical oceanographic workshop at Big Sky, Montana, in January 1980. At this workshop, a group of expert scientists assessed the current state of knowledge with regard to the physical oceanographic questions that must be answered for the SDP for high-level radioactive waste; recommended necessary research in areas where knowledge is incumplete or inadequate; and identified other ongoing programs with which important liaisone should be made and continued. The workshop report is a collection of those presentations and recommendations. ${ }^{8}$

Following these recommendations, the SDP will undertake tasks of high priority as study sites are identified. The first priority is the essential site characterization work, such as deep current statistics, hydrographic work, and radon measurements. For each site the SDP plans pilot experiments to include work which depends only on existing instrumentation. The areas of concern for the benthic boundary layer studies are escapement and reentrainment 
mechanisms. For each site which appears to be dynamically different on the basis of the pilot experiments, we plan to field benthic boundary layer experiments similar to those reported in Armi and $D^{\prime}$ Asaro. ${ }^{56}$ These experiments will be designed to examine both types of processes that bear upon the detachment of benthic boundary layer water; i.e., processes which are coupled with the mesoscale, such as Ekman layer convergence and divergence, and processes which are topographically induced.

As this work is fielded, two other activities can be added which the workshop considered essential to the SDP field program. First, deep SOFAR floats $(4000 \mathrm{~m})$ can be deployed on each cruise. This would require some new technology which could be available within $2 \mathrm{yr}$. Such experiments will allow us to study the Lagrangian transport and water spread in the site areas. ${ }^{57}$ Second, pop-up float experiments were considered important for this program, and could be added to the bottom boundary layer work. These experiments involve carousels of floats that would be released on signal and would pop up to the surface giving a single vector measurement. These are currently being developed by H. T. Rossby at the University of Rhode Island.

Deep dye experiments which also require new technology were assigned a high priority. Historical data analysis of shallow open ocean Rhodamine dye experiments has begun. ${ }^{58}$ Besides obtaining data on horizontal spreading and vertical diffusivity in the open ocean, dye experiments would be useful in special process areas such as benthic boundary layers.

There are many recommendations that resulted from the Big Sky workshop; a single program could hope to fund only a few of them. Those listed above, along with the modeling work, will probably be the first tasks undertaken by the SDP. Some work will be partially funded by the SDP when opportunities to make measurements as a part of other programs become available. Examples of these cooperative efforts include the Rhodamine dye experiments and $\mathrm{Pu}$ measurements in the Pacific.
The first step towards understanding the relative significance of the various tasks recommended will be a "Big Envelope Workshop." This will be a meeting of a few experts who will perform all the "back-ofthe-envelope calculations" that can be done on the basis of current understanding. This meeting should cover all components (physical, biological, and geochemical) of the radionuclide transport problem from the far-field sediments to man. Through such a workshop, weak links in our knowledge may be identified, research priorities may be readjusted, and parameterization of important processes for numerical modeling may be better defined. This workshop will be held shortly after the January 1981 SDP Biological Oceanography Workshop: Other tasks from these workshops will probably begin as the work develops and funds are available.

\section{Summary}

The U.S. Subseabed Disposal Program is conducting environmental studies directed at assessing possible ecosystem and human health effects from radionuclides that may be released from high-level nuclear waste canisters in the deep sea and transported through the water column to the ocean surface. Current or planned investigations are attempting to de-: termine benthic community structure; benthic community metabolism; the biology of deep-sea mobile scavengers; the faunal composition of midwater nekton; rates of microbial processes; radiation sensitivity. of deep sea fauna; $\mathrm{Pu}, \mathrm{Cs}$, and $\mathrm{Sr}$ measurements in the Pacific; site-related current meter moorings; repeated. hydrographic/geochemical sampling; bottom bound: ary layer escapement-reentrainment experiments; deep SOFAR float experiments; and pop-up float experiments.

The data obtained from these studies, along with data from the literature, are being used in the SDP environmental modeling effort. l'hese models will allow parametric studies to be made of the impact on the ocean environment and on man of potential releases of radionuclides. 


\section{References}

1. L. S. Gomez et al, "Biological Studies of the United States Subseabed Disposal Program," Proceedings of the 3rd NEA Seminar on Mar Radioecol, Tokyo 1979, NEA/OECD (1980) 35.

2. L. S. Gomez et al, "Biological Ramifications of the Subseabed Disposal of High-Level Nuclear Waste," Proceedings of the 2nd Int'l Ocean Dumping Symp, Woods Hole, MA, 1980.

3. G. L. Weatherly, "A Numerical Study of Time-Dependent l'urbulent Ekman Layers Over Horizontal and Sloping Bottoms," I Phys Occanog, 5 (1975) 288

4. G. L. Weatherly and P. G. Martin, "On the Structure and Dynamics of the Oceanic Bottom Boundary Layer," I Phys Occanog, 8 (1978) 557.

5. A. R. Robinson and D. B. Haidvogel, "Dynamical Forecast Experiments With a Barotropic Open Ocean Model" (in preparation).

6. D. B. Haidvogel, A. R. Robinson, and E. E. Schulman, "The Accuracy, Elficiency, and Stability of 'l'hree Numerical Models With Application to Open Ocean Problems," I Computariuntl Plity, J4 (1,200) 1.

7. K. Bryan and L. J. Lewis, "A Water Mass Model of the World Ocean," I Geophys Res, 84 (1979) 2503

8. M. G. Marietta and A. R. Robinson, Subseabed Disposal Program Physical Oceanography Workshop: Proceedings of a Workshop on Pliysical Occanography Related to the Subseabed Disposal of HighLcvel Nuclear Waste, SAND80-1776 (Albuquerque, NM: Sandia National Laboratories, 1980)

9. W. C. Renfro et al, I Fish Res Bd Canada, 32 (1975) 1339.

10. M. L. Young, I Mar Biol Assoc, U.K., 55 (1975) 583.

11. C. J. Walters, "Systems Ecology: The Systems Approach and Mathematical Models in Ecology," Fundamentals of Ecology, E. D. Odum, ed. (Philadelphia: W. B. Saunders Co., 1979) 276.

12. M. E. Vinogradov, "Feeding of Deep-Sea Zooplankton," Rapp Proc Verb Cons Perm Int Explor Mer, 153 (1962) 114

13. M. N. Soklova, "Weight Characteristics of Meibenthos From Different Parts of the Deep-Sea Tropic Regions of the Pacific Ocean," Occanology 10 (1970) 266

14. K. J. Menzies et al, Abyssal Environment and Ecology of Worid Orrans (New York: John Wiley and Sons, 1973).

15. R. L. Haedrick and G. T. Rowe, "Megafaunal Biomass in the Decp Sea," Nature, 269 (1977) 141

16. G. T. Rowe et al, "Benthic Biomass Estimates From the Northwestern Atlantic Ocean and the Northern Gulf of Mexico," L'L' sil K's, LI (1Y'4) 64l.

17. B. R. Burnett, "Quantitative Sampling of Microbiota of the Deep-Sea Benthos: I. Sampling Techniques and Some Data From the Abyssal Central North Pacific," Deep Sea Res, 24 (1977) 781

18. H. 'l'hiel, "l'he Size Structure of the Deep-Sea Benthos." Int Rev Ges Hydrobiol, 60 (1975) 575

19. M. E. Vinogradov, Vertical Distribution of the Oceanic Zooplankton (Moscow: Nauka Publ. House, 1968), (Transl. Israel Prog for Sci. Transl., Jerusalem, 1970).

20. D. C. Gordon, Jr., "Distribution of Particulate Organic Carbon and Nitrogen at Oceanic Station in the Central Pacific," Deep Sca Res, 18 (1971) 1127.

21. D. C. Gordon, Jr., "Variability of Particulate Organic Carbon and Nitrogen Along the Halifax-Bermuda Section," Deep Sea Res, 24 (1977) 257.

22. Scripps Institution of Oceanography, Data Report: Climax I Expedition, SIO Ref. 74-20 (1974).

23. Scripps Institution of Oceanography, Data Report: Climax II Expcdition, SIO Ref. 75-6 (1975).

24. J. D. H. Strickland, "Measuring the Production of Marine Phytoplankton," Fis Res Bd Canada Bull, 122 (1960).

25. R. W. Sheldow et al, "Structure of Pelagic Food Chain and Relationship Between Phytoplankton and Fish Production," I Fish Res Bd Canada, 34 (1977) 2344.
26. J. V. Hannan and D. H. Evans, “Water Permeability in Some Euryhaline Decapods and Limulus Polyphemus," Comp Biochem Physiol, 44A (1973) 1199

27. K. L. Smith, Jr., "Sediment Community Respiraliun," Subscabed Ammual Report - 1979 (D. M. Talbert, ed), SAND802577/II, April 1981 (Albuquerque, NM: Sandia National Laboratories, 1980)

28. A. C. Redfield et al, "The Influence of Organisms on the Composition of Seawater," The Sea, Vol. 2 (M. N. Hill, ed), (New York: Wiley Interscience, 1963).

29. F. D. King et al, "Plankton Metabolic Activity in the Eastern North Pacific," Deep Sea Res, 25 (1978) 689

30. V. S. Schultz, A Bibliography of Marinc Radiation Ecology Prepared for the Seabed Program, SAND79-7102 (Albuquerque, NM: Sandia National Laboratories, 1980).

31. R. R. Hessler and P. A. Jumars, "Abyssal Community Analysis From Replicate Box Cores in the Central North Pacific," Decp Sea Res, 21 (1974) 185.

32. R. R. Hessler and P. A. Jumars. "Ahyssal Cnmmunities and Radioactive Waste Disposal," Occanus, 20 (1972) 41.

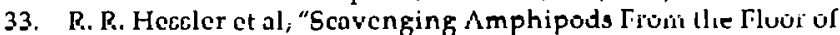
the l'hilippine Trench," Dev $\mu$ Jun Res, 25 (1978) 1029.

34. H. W. Jannasch et al, "Microbial Degradation of Organic Matter in the Deep Sea," Scicnce 171 (1971) 673

35. M. M. Pamatmat, "Benthic Community Mctabolisñ on tho Continental Terrace and in the Deep Sea in the North Pacific," Int'l Rev Ges Hydrobiol, 58 (1973) 345

36. K. L. Smith, Jr. and J. M. Teal, "Deep Sea Benthic Community Respiration: An in situ Study at 1850 Meters," Scicnce, 179 (1973) 282

37. K. L. Smith, Jr. and R. R. Hessler, "Respiration of Benthopelagic Fishes: in situ Measurements at 1230 Meters," Science, 184 (1974) 72 .

38. K. L. Smith, Jr. et al, "A Free Vehicle for Measuring Benthic Community Metabolism," Limnol Occanogr, 21 (1976) 164.

39. C. O. Wirsen and H. W. Jannasch, "Decomposition of Solid Organic Material in the Deep Sea," Environm Sci and Technol, 10 (1976) 880

40. K. L. Smith. Ir.. "Renthir Community Respiratinn in the NWW Atlantic: in situ Measurements From 40 to 5200 Meters," Mar Bivl, 47 (1978) 337.

41. K. L. Smith, Jr., G. A. White, and M. B. Laver, "Oxygen Uptake and Nutrient Exchange of Sediments Measured in Sttu Using a Frep Vehirle Grah Respirometer," Deop Sea Res, 26 (1979) 337

42. A, S. Dietz and A. A. Yayanns. "Silica Rel Media for Isnlating and Studing Bacteria Under Hydrostatic Pressure," Applied Environ Microbiol, 36 (1978) 996.

43. A. A. Yayanos, A. S. Dietz, and R. Van Boxtcl, "Isolation of a Deep-Sea Barophilic Bacterium and Some of Its Growth Chararteristirs," Srimer, 205 (1979) 808

i $A . \Omega$. Yayranoc and $A, \delta$, Dicts; "Thermal Inuclivaliun of CNIPT-3, a Deep-Sea Barophilic Bactcrium," Abstracts 00ll Aili Mecting Amer Soc Microbiol (1980)

45. A. A. Yayanos et al, "Kinetics of Reproduction of the Barophilic Bacterium CNPT-3, as a Function of Pressure and Temperature," Abstrncts 80th Ann Mecting Amer Soc Microbiol (1980).

46. P. H. Wiebe, S. H. Boyd, and C. Winoet, "Particulate Matter Sinking to the Deep-Sea Floor at $2000 \mathrm{~m}$ in the Tongue of the Ocean, Bahamas, With a Description of Now Sedimentation Trap," I Mar Res. 34 (1976) 341.

47. S. Honjo, "Sedimentation of Material in the Sargasso Sea at a 5367-m Deep Station," I Mar Res, 36 (1978) 469.

48. K. L. Smith, Jr. et al, "Free Vehicle Capture of Abyssopelagic Animals," Decp Sca Res, 26 (1979) 57.

49. Mode Group, "The Mid-Ocean Dynamics Experiment," Deep Sca Res, 25 (1978) 859

50. M. D. Earle, "Current Measurements in the Eastern Central North Pacific Ocean," Decp Sea Res, 22 (1975) 875

51. B. A. Taft et al, "Low-Frequency Near-Bottom Currents in the Central North Pacific," to be published in / Geophys Res (1980). 
52. W. P. Schimmel, Jr. and W. N. Sullivan, Experimental Study of Thermally Induced Buoyant Plumes in Water, SAND75-0036 (Albuquerque, NM: Sandia National Laboratories, 1975).

53. S. L. Kupferman and D. E. Moore, "Physical Oceanographic Characteristics Influencing the Dispersion of Dissolved Tracers Released at the Seafloor in Selected Deep Ocean Study Areas," Presented at 2nd Int'l Ocean Dumping Symp., Woods Hole, MA, 1980.

54. V. T. Bowen, "Oceanic Distributions of Radionuclides From Nuclear Weapons Testing," Presented at American Nuc Soc Symp on Mcthods for Seabed Disposal of Nuc Wastes, 16 June 1977, New York City.

55. V. T. Bowen et al, "Fallout Radionuclides in the Pacific Ocean; Vertical and Horizontal Distributions, Largely From GEOSECS Stations," Earth and Planctary Sci Lirs, (1980) in press.

56. L. Armi and E. D'Asaro, "Flow Structures of the Benthic Ocean," I Gecophys Res (1980).

57. H. T. Rossby, "SOFAR Floats Track Deep Ocean Currents, EDIS (NOAA), (1978) 7

58. T. E. Ewart, Personal Communication (1980). 


\section{DISTRIBUTION:}

TID-4500-R68 UC-70 (314)

DOE/DBER (2)

Washington, DC 20545

Attn: R. L. Watters

C. L. Osterberg

DOE/ONWN

Washington, DC 20545

Attn: D. G. Boyer - Mail Stop B107

Bettis Atomic Power Laboratory (2)

West Mifflin, PA 15122

Attn: C. A. Detrick

$$
\text { J. L. Rider }
$$

\section{Colorado State University}

Ft. Collins, CA 80521

Attn: F. W. Whicker

Concepts Development Incorporated (5)

Post Office Box 14314

Albuquerque, NM 87191

Attn: D. W. Jackson

National Oceanographic and Atmospheric Administration

Washington, DC 20545

Attn: K. Park

Oregon State University (2)

Corvallis, ÓR $\overline{9} \overline{3} \overline{3} 1$

Attn: G. R. Heath

W. G. Pearcy

Pacific Northwest Laboratories

Richland, WA 99352

Átn: W. L. Templeton
Scripps Institution of Oceanography (16)

La Jolla, CA 92037

Attn: R. R. Hessler (5)

M. M. Mullin

K. L. Smith (5)

A. A. Yayanos (5)

University of Washington (5)

Seattle, WA 98195

Attn: W. R. Schell
A. Seymour
K. L. Jackson
J. P. Geraci
P. A. Jumars

Washington State University

7.nolngy Department

Pullman, WA 99163

Attn: V. S. Schultz

Woods Hole Oceanographic Institution (2) Woods Hole, MA 02545

Attn: V. T. Bowen

C. D. Hollister

4500 E. H. Beckner

4530 R. W. Lynch

4536 D. R. Anilerisüı

4536 L. S. Gomez (100)

4536 J. Lipkin

4536 C. M. Percival

4536 D. M. Talbert

5521 M. G. Marietta (25)

8214 M. A. Pound

3141 L. J. Erickson (5)

3151 W. L. Garner (3)

For: DOE/TIC (Unlimited Release) 


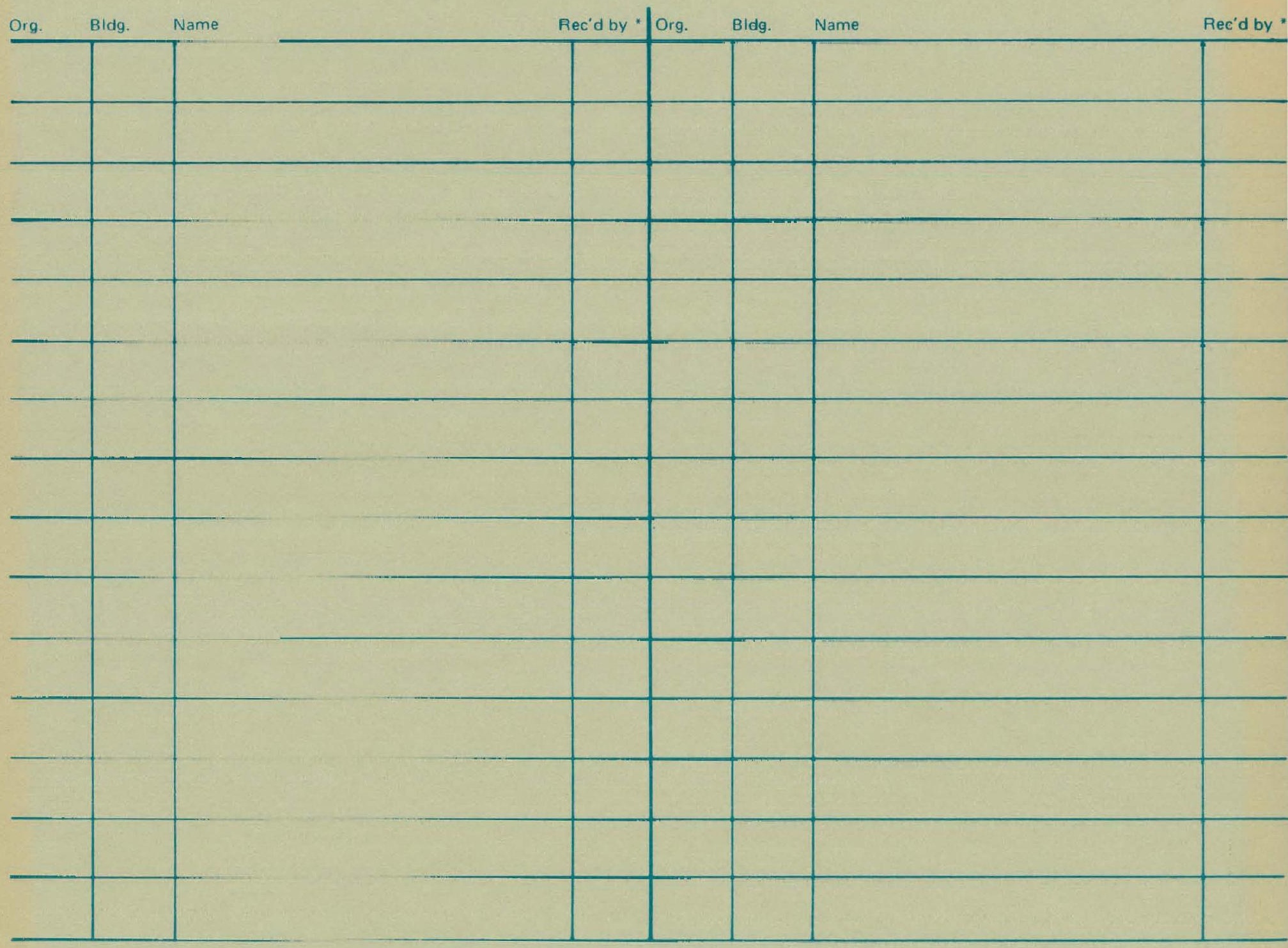

